\title{
Construction and Application of Internal Medicine Teaching Interactive Course based on 5-Star Instructional Model
}

\author{
https://doi.org/10.3991/ijet.v14i03.10102 \\ Qiong Fang \\ Hefei Technology College, Hefei, China \\ $18355365221 @ 163 . \mathrm{com}$
}

\begin{abstract}
With the continuously deepening education reform, to realize effective teaching as much as possible, teaching quality improvement becomes the precondition of building a moderately prosperous society. At the same time, teaching informationization also requires teachers to pay attention to keeping abreast of the times, adopt multimedia means for teaching and improve teaching efficiency. As new teaching concepts and teaching methods are required in the new era, five-star teaching theory focusing on problem-solving and the consistency of the teaching process and the learning process provides theoretical guidance for curriculum design through four steps, activating original knowledge, displaying and demonstrating new knowledge, trying application exercise, and integrated mastery. The classroom teaching interactive response system (CIRS) which attaches great importance to the interactive feedback between teachers and students, strengthens students' participation in the classroom can have a real-time control of teaching progress and adjust the teaching content in real time. Combination of five-star teaching theory and CIRS has the optimum effect on improving effective teaching. With internal medicine teaching course as the example, the study conducted smartphone CIRS course teaching model based on 5-Star Instructional Model, carried out experiments, and evaluated the experiment results through questionnaire survey. Experiment results show that the teaching mode received students' full recognition, improved students' internal medicine teaching course scores and achieved good teaching results.
\end{abstract}

Keywords - 5-Star Instructional Model; classroom teaching interactive response system (CIRS); smartphone; internal medicine teaching

\section{$1 \quad$ Introduction}

Five-star teaching principle (also called 5-Star Instructional Model, Frist Principles of Instruction) as a new teaching theory originally proposed by David Merrill to solve the problem of over-valuing information presentation but neglecting effective teaching in multimedia teaching and E-Learning teaching process [1]. According to 5-Star Instructional Model, we cannot put the incidental before the fundamental, or forget 
"teaching" subject of instruction in the teaching process during multimedia and network teaching. The purpose of teaching lies in obtaining effective teaching instead of presenting teaching information with electronic information equipment [2]. Teaching doesn't mean information presentation and efficient teaching means that students take the initiative and obtain high and efficient learning effect. Although 5-Star Instructional Model was proposed in early this century, it was well received by Chinese educators. In spite of not extensive researches, scholars in primary education, secondary education, and higher education pay attention as it involves widespread subject areas. Higher education mainly involves disciplines such as computer software, computer applications, linguistics, and education. According to some research findings [3], 5-Star Instructional Model has a significantly positive effect on the improvement of teaching quality.

Teaching Interactive Response System [4] as a network platform based on modern information technologies such as computers, network, multimedia devices, infra-red wireless technology has the functions of recording, statistics and testing. Classroom Teaching Interactive Response System (CIRS) is a teaching application system with electronic products such as hand-held sensors, wireless voting devices, and smart phones as the carrier to realize teacher-student interaction and information feedback in the classroom. CIRS system [5] proposed by Stanford University was widely applied in Europe and the United States after the development of infrared wireless. China didn't introduce CIRS system until 2000 and started to build a CIRS-based teaching model. After Peking University evaluated the teaching effect of CIRS in 2010, Chinese colleges and universities started to test CIRS teaching. With the emerging of CIRS teaching in China with extremely popularizing rate, and rare application in the ordinary classroom, it is mainly used in classroom teaching of primary and middle schools. It obviously improved the students' learning interest and teaching effect. The reasons why it can be rarely even involving professional courses in colleges and universities are because CIRS requires high cost with great difficulties maintenance management [6].

Improvement of education quality is the precondition for China to build a moderately prosperous society. Learning at low efficiency not up to achieve the expected goal has become the main problem of education in China at this stage because of the failure of implementing effective teaching in the teaching process. As stated in "Decade of Education Informationization Development (2011-2020)" by Ministry of Education [7], we must vigorously promote information technology and course integration. Highly professional internal medicine teaching can only provide limited knowledge based on teaching materials and meanwhile requires practical and applied talents. With close relation between teaching activities and clinical activities, it is a subject-allowing no mistaken in specific social practice. Therefore, effective teaching is extraordinarily important. Under the guidance of the new education theory and 5Star Instructional Model, CIRS which can improve the classroom teaching mode and teaching process is not only good for enhancing the learning effect and efficiency of internal medicine teaching, but also good for cultivating medical talents to effectively integrate the teaching content with clinical practice. Meanwhile, it can provide theo- 
Paper-Construction and Application of Internal Medicine teaching interactive course...

retical and empirical reference for effective teaching in relevant professional courses in the medical domain.

\section{State of the Art}

Since the proposal of 5-Star Instructional Model, it has been applied to domestic and overseas teaching. Collins [8] established a set of work learning method design and evaluation criteria based on 5-Star Instructional Model for application in 68 courses. Under the guidance of Merill, Brigham Young University Hawaii set up online entrepreneurship courses and "Biology 100" course based on 5-Star Instructional Model, which received widespread recognition among students. More than $80 \%$ of students said they developed their interest in the course. Dow [9] carried out taskcentered course design by combining college online English writing with 5-Star Instructional Model, and obtained good teaching results. Cheung [10] introduced 5-Star Instructional Model into China and carried out studies. He pointed out that its principle of improving students' learning initiative, efficiency and effect is the goal of quality teaching in the multimedia and network-teaching environment, conducted teaching experiments in some schools and obtained good results. Afterwards, some scholars carried out studies and practice on 5-Star Instructional Model. Zhang [11] applied 5-Star Instructional Model to modern Chinese micro-class teaching, and found its good popularity and utility. Ren [12] carried out teaching process design and practice with 5-Star Instructional Model, which effectively improved students' learning initiative and classroom teaching efficiency.

CIRS was increasingly applied at home and abroad in recent years. Blackwell \& McKee [13] found that IRS was very effective when instructing economics to noneconomics students with IRS system. Aldabbagh et al. [14] evaluated the IRS teaching effect of Indian medical undergraduates by experimental method, and found that the scores in experimental group were $8 \%$ to $10 \%$ higher than that in the control group after experiment, and IRS significantly enhanced teacher-student interaction. Ehsan Gharaie conducted four years' IRS experiment on the project management course with 323 students from RMIT University as experimental subject, and found that students loved the teaching model very much and teaching results were very efficient. Research found that CIRS optimized information feedback when instructing Educational Communication course to educational technology undergraduate students with CIRS. Cui et al. found that students participated more, increased their interest in learning and deepened their understanding and mastery of knowledge while conducting pathology case teaching with CIRS. Researchers also found through empirical research that application of self-developed CIRS in college s classroom greatly promoted students' initiative and interactivity, regulated classroom atmosphere, and strengthened students' mastery of knowledge. Some research findings also showed good teaching effect of IRS in the classroom of primary and secondary schools.

This study mainly has two innovative points as follows by combining the existing domestic and foreign research and the main content of this study: first is the application of 5-Star Instructional Model to smartphone CIRS. Only the teaching result of 
CIRS, which was well received by educators, was investigated when applied in classrooms. But it did not combine 5-Star Instructional Model with CIRS to jointly investigate the effect of both on course teaching. Second, the abo.ve model was applied to medicine teaching for the first time. At this stage, information retrieval shows rare researches on the separate application of 5-Star Instructional Model or smartphone CIRS in medical theory teaching. Researches on medicine courses by integrating both remain blank. Based on 5-Star Instructional Model and smartphone CIRS, this study conducted teaching design on medicine courses, and provided a brand new efficient teaching model for teaching activities

\section{Theory Construction}

\subsection{5-Star Instructional Model}

Under the principle of 5-Star Instructional Model focusing on problem-solving, the teaching process includes four continuously cycling stages: activating original knowledge- displaying and demonstrating new knowledge- trying application exercise-integrated mastery. There are five links in 5-Star Instructional Model:

- Focusing on the problem, i.e., to obtain the specific expected learning effect aiming at the teaching goal.

- Activating original knowledge, i.e. to inspire students to recall previous experiences or knowledge related to the course.

- Demonstrating new knowledge, i.e., students think independently, and learn new knowledge from no cognition or insufficient cognition to mature and systematic cognition.

- Applying new knowledge, i.e., the learner exercises or solves problems according to the newly learned knowledge that has just been learned.

- Integrated mastery, i.e. to apply the newly learned knowledge to your life and study.

The outer layers of the four stages of continuous circulation are - structureguidance-coaching-self-examination, which shows that 5-Star Instructional Model not only pays attention to the teaching process, but also emphasizes the learning process. The consistency of teacher's teaching process and students' learning process can achieve effective teaching and can be regarded as the efficient and quality teaching. The 5-Star Instructional Model is shown in Figure 1. 


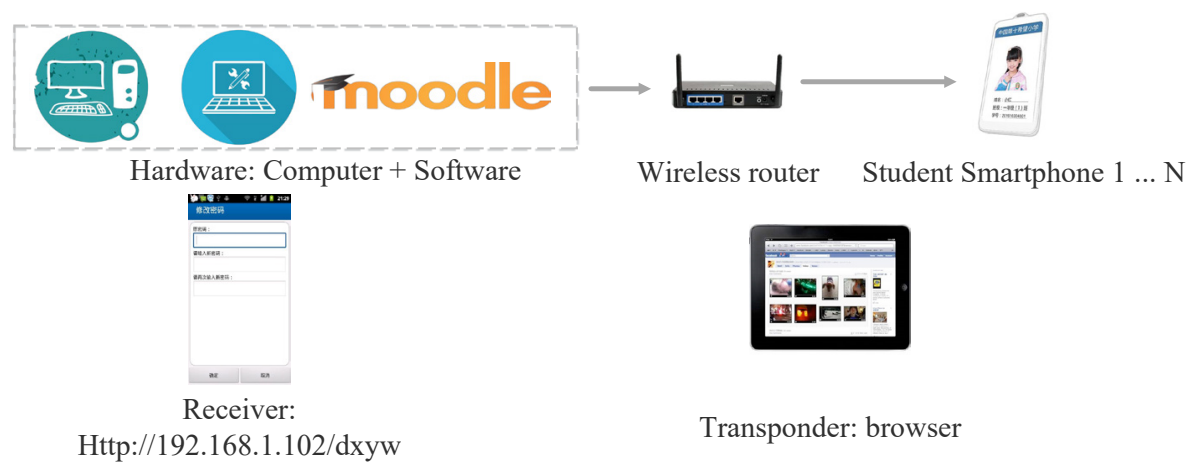

Fig. 1. 5-Star Instructional Model Diagram

\subsection{Smartphone CIRS}

CIRS as a relatively new type of classroom teaching media can help teachers and students to establish an interactive learning model by means of collecting, transmitting, processing and displaying information. Each student has a mobile electronic device for signal transmission to answer the teacher's questions and participate in the teaching activities. Teachers use the feedback results displayed by computers and other devices to control students' learning process and to adjust teaching strategies and contents any time.

Design concept: The design concept of this study is to establish a "software platform smartphone" replace traditional remote and emitters with their own smartphones.

Moodle software platform: In this study, Moodle learning platform was used as the software platform of smartphone CIRS. Moodle, which is free of charge, has strong interactivity. Comparison between Moodle and other online interactive websites are shown in Table 1.

Table 1. Comparison between Moodle online interactive websites

\begin{tabular}{|l|l|l|}
\hline Convenience & \multicolumn{1}{|c|}{ Moodle } & \multicolumn{1}{|c|}{ Online interactive websites } \\
\hline Stability & $\begin{array}{l}\text { Simple and convenient, interactive, and } \\
\text { highly popularity degree, free of charge }\end{array}$ & $\begin{array}{l}\text { Not reliable, low application in } \\
\text { educational field, troublesome } \\
\text { use of English version }\end{array}$ \\
\hline Type of interaction & Stable, fast, stand-alone & $\begin{array}{l}\text { Limited to internet speed } \\
\text { mentation }\end{array}$ \\
\hline System function & $\begin{array}{l}\text { Powerful, completely keep interactive } \\
\text { records }\end{array}$ & $\begin{array}{l}\text { Single, choice questions, com- } \\
\text { pletion questions, true or false } \\
\text { questions, etc. }\end{array}$ \\
\hline Expense & Campus network, free & $\begin{array}{l}\text { General, no interactive records } \\
\text { kept }\end{array}$ \\
\hline
\end{tabular}

Smartphone CIRS building: After installing Moodle on the campus network server, CIRS platform can be used throughout the school and can be built without internet only with a wireless router and computer. After installing Moodle on the computer in the classroom, setting network and then inputting student list, creating the 
course, students can log in with name and student number on the smartphone through the wireless router to interact with the teacher. The CIRS stand-alone platform based on Moodle is shown in Figure 2.

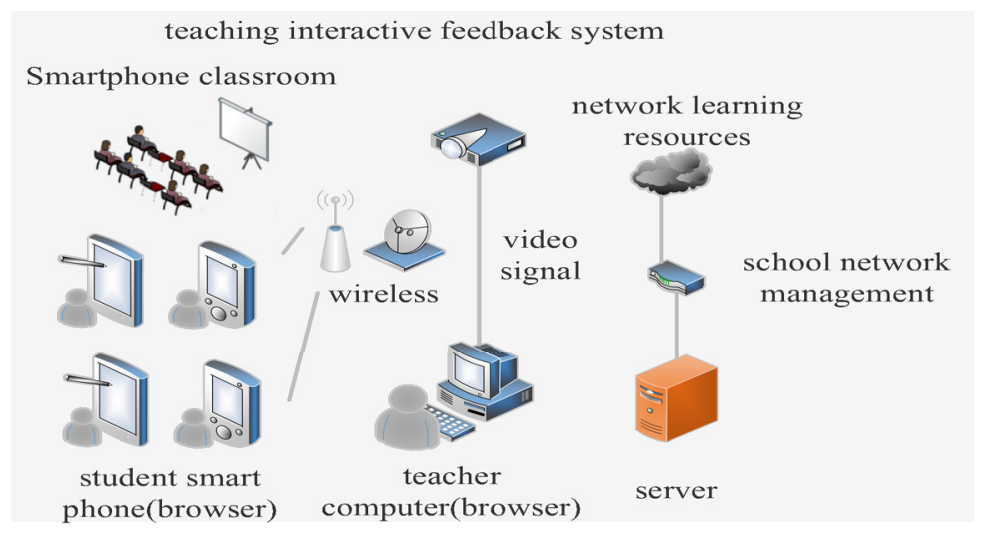

Fig. 2. Structure of smartphone CIRS stand-alone platform

The shared platform of smartphone CIRS requires multimedia classrooms, including computers, projectors, wireless routers, and students' own smart phones. Students establish communication with the CIRS system with the wireless network and interact with teachers on the computer after logging in to Moodle through a browser on a smartphone. The server saves results for processing and analysis. When viewing the feedback results, the system extracts the analyzed results and outputs them on the teacher's computer and student's mobile phone, or projects onto a white screen by a computer to form interactive feedbacks. Moodle-based CIRS sharing platform is shown in Figure 3.

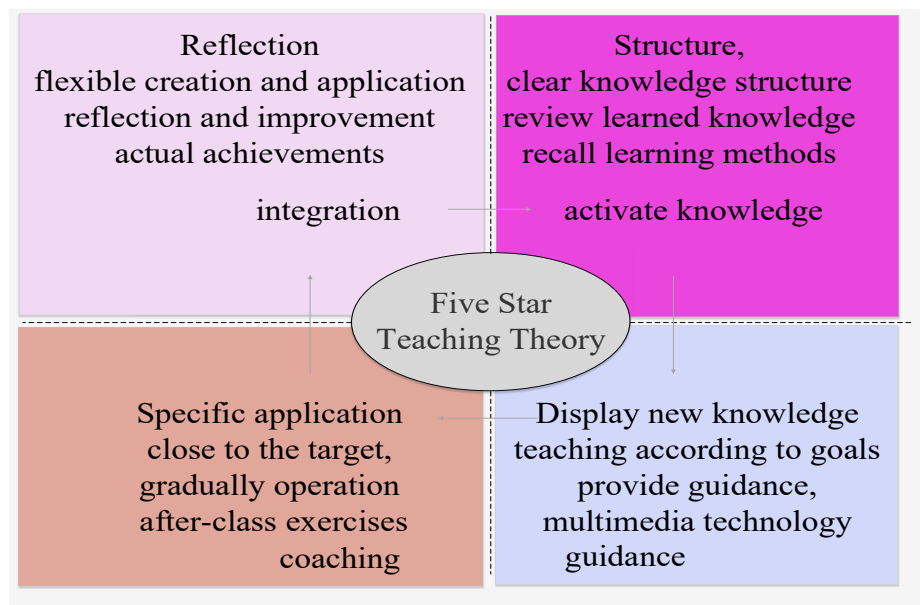

Fig. 3. Structure of smartphone CIRS sharing platform 


\section{Teaching Example and Teaching Effect}

\subsection{Teaching example}

This study conducted internal medicine teaching course design based on 5-Star Instructional Model and smartphone CIRS, and paid attention to the theoretical and strategic issues in teaching design. In other words, this study adopts the combination of theory and strategy to carry out practical design activities under the guidance of the theory for building internal medicine teaching course. Under the guidance of 5-Star Instructional Model, this study goes from the easy to the difficult and simplifies from abstract to explicit for teacher-student interaction through smartphone CIRS and conducted evaluation. The construction method of CIRS for internal medicine teaching course based on 5-Star Instructional Model is shown in Figure 4

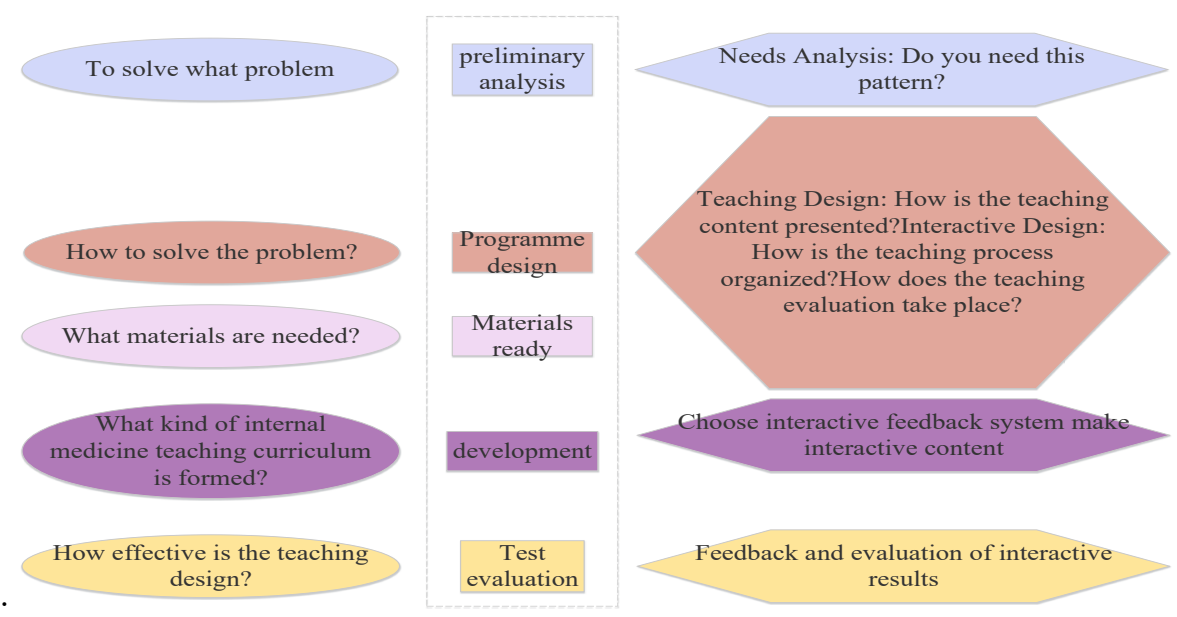

Fig. 4. The construction method of CIRS for internal medicine teaching course based on 5-Star Instructional Model

Based on above teaching design concept, under the guidance of 5-Star Instructional Model, this study constructs smartphone CIRS teaching model. There are mainly three steps. Firstly, the teacher creates an interactive activity and the students respond, i.e. the teacher designs different questions according to the teaching tasks and teaching contents, and the students input answers and submit. Secondly, the teacher assesses the student's grades and then gives real-time feedback. The system may conduct statistics of some questions such as choice questions, completion questions, true or false questions, etc. Teacher may manual score subjective questions or ask students to questions after releasing answers and criteria and opening cross-scoring function. Thirdly, the CIRS statistically analyzes students' answers and outputs statistical data to reflect the students' learning situation for teacher to adjust the teaching, and answer questions based on the statistical results. The whole process is under the guidance of 5-Star Instructional Model. The teacher needs to combine teaching objectives, diffi- 
culties and students' learning characteristics for the design of questions. Before interactive feedbacks, the teacher needs to activate the existing experience and knowledge (previous knowledge), and then helps students get familiar with the new teaching contents (argumentation of new knowledge). In the process of the interactive feedback, it means to apply and practice new knowledge for integrated mastery of new knowledge. On one hand, it fully reflects students' cognition and mastery of new knowledge. On the other hand, teachers and students can think, summarize, discuss the feedback results, and finally connect the learned knowledge with real life. Internal medicine teaching requires applying what they have learned to clinical practice in a correct way. The course construction of CIRS for internal medicine teaching course based on 5-Star Instructional Model is shown in Figure 5.

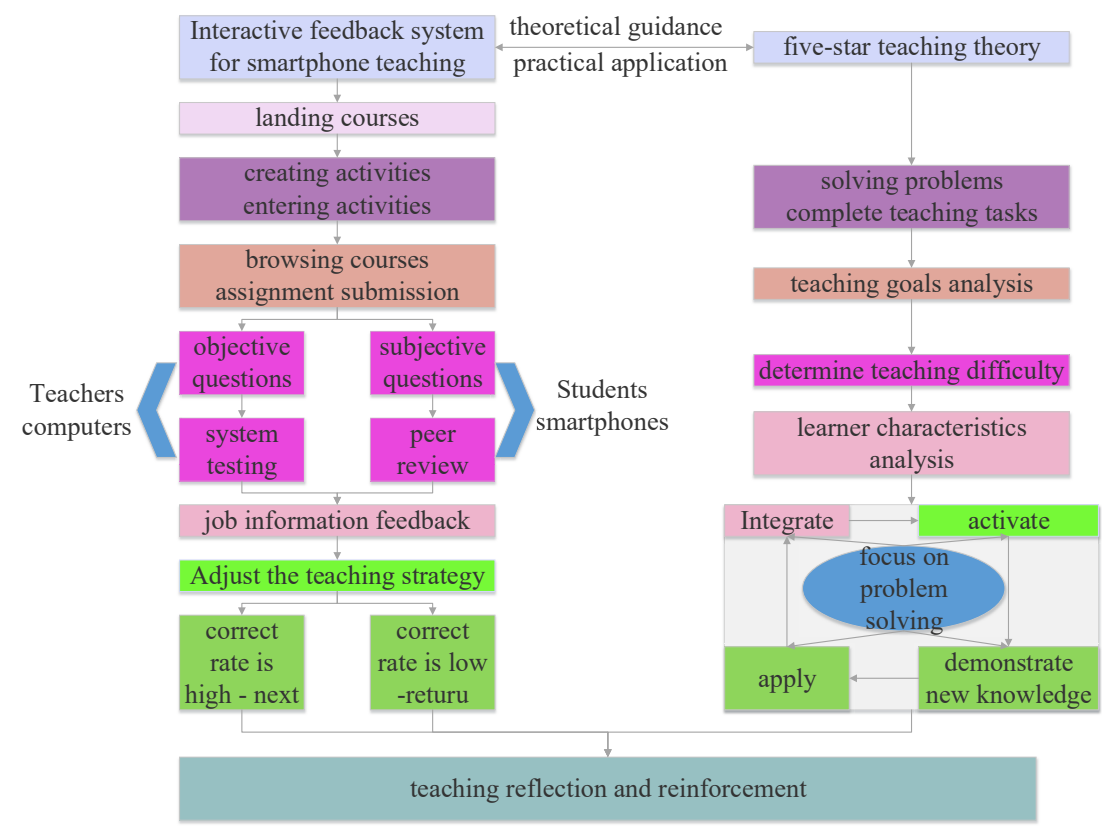

Fig. 5. The course construction of CIRS for internal medicine teaching course based on 5-Star Instructional Model

According to the results of the teaching model shown in Figure 5, under the guidance of 5-Star Instructional Model, based on smartphone CIRS, at the stage of activating previous knowledge, the teachers need put up a question or depict the old knowledge and provide experience for smooth transition of old and new knowledge. At the stage of demonstrating new knowledge, teachers need to organize and display the teaching content, and at the same time carry out the teaching interactive feedback design, and conduct design of learning and guiding. At the application stage, students use a smart phone with the CIRS to answer questions, exercises or tests designed by the teacher. Next, the system and the teacher evaluate the answers. At the integrated mastery stage, teacher further intensifies the teaching content, helps students to re- 
view and consolidate. Students should also re-think after class. The construction template of CIRS for internal medicine teaching course based on 5-Star Instructional Model is shown in Table 2.

Table 2. The construction template of CIRS for internal medicine teaching course based on 5Star Instructional Model

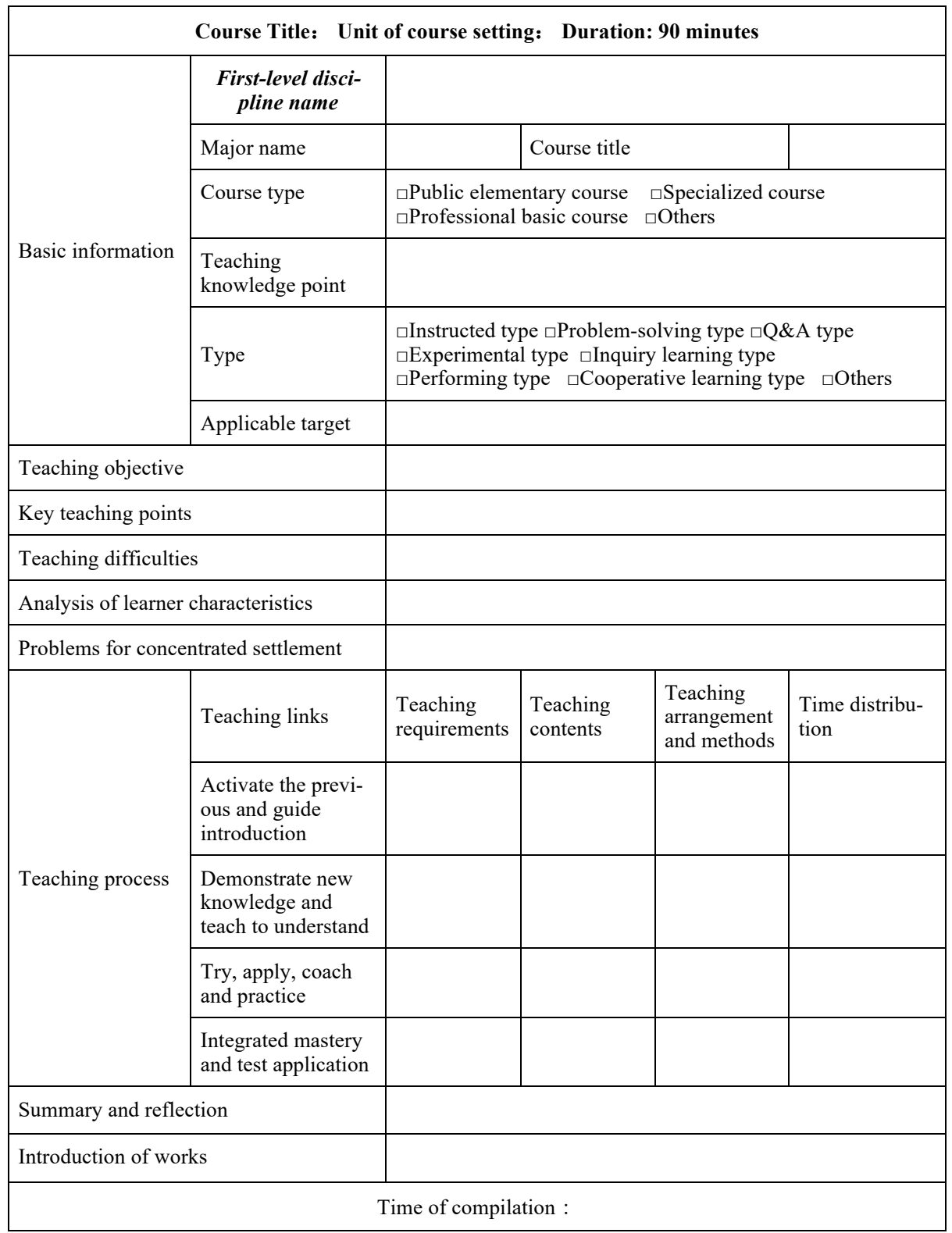


This study selected chronic bronchitis, chronic obstructive pulmonary disease and relevant knowledge points in the clinical medicine specialty as the teaching contents, designed and presented the teaching cases by using above teaching design construction method, construction mode and construction template. Details are shown in Table 3 as below.

Table 3. Teaching cases of CIRS for internal medicine teaching course based on 5-Star Instructional Model

\begin{tabular}{|c|c|c|c|c|c|}
\hline \multicolumn{6}{|c|}{$\begin{array}{l}\text { Course title: chronic bronchitis and chronic obstructive pulmonary disease } \\
\text { Unit of course setting: } S \text { University Duration: } 2 \text { credit hours }\end{array}$} \\
\hline \multirow{6}{*}{$\begin{array}{l}\text { Basic } \\
\text { information }\end{array}$} & First-level disci- & \multicolumn{4}{|c|}{ clinical medicine } \\
\hline & Major & $\begin{array}{l}\text { Internal medi- } \\
\text { cine }\end{array}$ & Course title & \multicolumn{2}{|c|}{ Internal medicine } \\
\hline & Course type & \multicolumn{4}{|c|}{ Specialized course } \\
\hline & $\begin{array}{l}\text { Teaching } \\
\text { knowledge point }\end{array}$ & \multicolumn{4}{|c|}{ Chronic bronchitis and chronic obstructive pulmonary disease } \\
\hline & Type & \multicolumn{4}{|l|}{ Instructed type } \\
\hline & Applicable target & \multicolumn{4}{|c|}{ Sophomores of College of Traditional Chinese Medicine } \\
\hline \multicolumn{2}{|c|}{ Teaching objective } & \multicolumn{4}{|c|}{$\begin{array}{l}\text { Knowledge and Skills. Mastery of diagnosis and treatment methods } \\
\text { of chronic bronchitis and chronic obstructive pulmonary disease, and } \\
\text { proficient application in practical problems. Enhance students' } \\
\text { specialty literacy of internal medicine and strengthen clinical practi- } \\
\text { cal ability. } \\
\text { Teaching process and methods. (1) Students autonomously preview } \\
\text { basic knowledge of chronic bronchitis and chronic obstructive } \\
\text { pulmonary disease through teaching materials and courseware. (2) } \\
\text { Students seek solutions for previewed contents by independent } \\
\text { collaborative learning. (3) Teachers guide students to solve problems } \\
\text { step by step with drive problem-driven teaching contents. (4) Stu- } \\
\text { dents try and apply experimental content by answering questions, } \\
\text { tests, etc. (5) Teachers summarize and raise new questions as ex- } \\
\text { tended exercise, and then students think after class } \\
\text { 3. Emotional attitude. Help students to experience the rich realistic } \\
\text { background of the application of chronic bronchitis and chronic } \\
\text { obstructive pulmonary disease, directly experience the operation of } \\
\text { dealing with real problems, and to strengthen students' learning } \\
\text { interest by question and scenario setting. }\end{array}$} \\
\hline \multicolumn{2}{|c|}{ Key teaching points } & \multicolumn{4}{|c|}{$\begin{array}{l}\text { How to flexibly apply knowledge of chronic bronchitis and chronic } \\
\text { obstructive pulmonary disease to solve practical problems in clinical } \\
\text { practice }\end{array}$} \\
\hline \multicolumn{2}{|c|}{ Teaching difficulties } & \multicolumn{4}{|c|}{$\begin{array}{l}\text { How to choose appropriate operations according to the characteris- } \\
\text { tics of actual cases to help students solve the clinical problems. }\end{array}$} \\
\hline \multicolumn{2}{|c|}{ Analysis of learner characteristics } & \multicolumn{4}{|c|}{ Students have learned before class. } \\
\hline \multicolumn{2}{|c|}{$\begin{array}{l}\text { Problems for concentrated set- } \\
\text { tlement }\end{array}$} & \multicolumn{4}{|c|}{$\begin{array}{l}\text { Diagnosis and treatment methods of chronic bronchitis and chronic } \\
\text { obstructive pulmonary disease }\end{array}$} \\
\hline Teaching & Teaching links & Teaching re- & Teaching & Teaching & Time \\
\hline
\end{tabular}


Paper-Construction and Application of Internal Medicine teaching interactive course..

\begin{tabular}{|c|c|c|c|c|c|}
\hline \multirow[t]{4}{*}{ process } & & quirements & contents & $\begin{array}{l}\text { arrangement } \\
\text { and methods }\end{array}$ & \\
\hline & $\begin{array}{l}\text { Activate the } \\
\text { previous and } \\
\text { guide introduction }\end{array}$ & $\begin{array}{l}\text { By activating } \\
\text { previous relevant } \\
\text { knowledge and } \\
\text { experience, } \\
\text { students can } \\
\text { clarify the } \\
\text { mastered } \\
\text { knowledge and } \\
\text { skills, which can } \\
\text { lay foundation } \\
\text { for students to } \\
\text { easily learn new } \\
\text { knowledge in the } \\
\text { classroom and } \\
\text { then improve } \\
\text { lecture effective- } \\
\text { ness. }\end{array}$ & $\begin{array}{l}\text { Put forward } \\
\text { and answer } \\
\text { questions, } \\
\text { the specific } \\
\text { questions are } \\
\text { as follows: } \\
\text { 1. What is } \\
\text { chronic } \\
\text { bronchitis } \\
\text { and chronic } \\
\text { obstructive } \\
\text { pulmonary } \\
\text { disease? } \\
2 . \text { What are } \\
\text { the symp- } \\
\text { toms of } \\
\text { chronic } \\
\text { bronchitis } \\
\text { and chronic } \\
\text { obstructive } \\
\text { pulmonary } \\
\text { disease? } \\
\text { 3. How to } \\
\text { treat chronic } \\
\text { bronchitis } \\
\text { and chronic } \\
\text { obstructive } \\
\text { pulmonary } \\
\text { disease? }\end{array}$ & $\begin{array}{l}\text { Statement and } \\
\text { guidance: state } \\
\text { problems one } \\
\text { by one, and } \\
\text { provide corre- } \\
\text { sponding } \\
\text { scenario } \\
\text { presentation } \\
\text { after putting } \\
\text { forward each } \\
\text { question so as } \\
\text { to help students } \\
\text { to quickly } \\
\text { comprehend } \\
\text { the question } \\
\text { and quickly } \\
\text { know the } \\
\text { correct solu- } \\
\text { tion. }\end{array}$ & 15 minutes \\
\hline & $\begin{array}{l}\text { Demonstrate new } \\
\text { knowledge and } \\
\text { teach to under- } \\
\text { stand }\end{array}$ & $\begin{array}{l}\text { Display and } \\
\text { demonstrate the } \\
\text { learning contents } \\
\text { at the class with } \\
\text { examples }\end{array}$ & $\begin{array}{l}\text { 1. The } \\
\text { teacher } \\
\text { presents the } \\
\text { new learning } \\
\text { contents in } \\
\text { the actual } \\
\text { clinical } \\
\text { practice } \\
\text { scenario. } \\
\text { 2. After } \\
\text { presenting } \\
\text { the problem, } \\
\text { guide stu- } \\
\text { dents to give } \\
\text { questions } \\
\text { analysis and } \\
\text { solutions. }\end{array}$ & $\begin{array}{l}\text { 1. Problem } \\
\text { display. Watch } \\
\text { actual clinical } \\
\text { cases and } \\
\text { explain the } \\
\text { essence of the } \\
\text { problem while } \\
\text { watching. } \\
\text { 2. Indicate and } \\
\text { guide. Teach- } \\
\text { ers guide } \\
\text { students to } \\
\text { analyze prob- } \\
\text { lems and solve } \\
\text { problems. }\end{array}$ & 30 minutes \\
\hline & $\begin{array}{l}\text { Try, apply, coach } \\
\text { and practice }\end{array}$ & $\begin{array}{l}\text { Clarify practical } \\
\text { clinical operation } \\
\text { and its imple- } \\
\text { mentation }\end{array}$ & $\begin{array}{l}\text { Summarize } \\
\text { the correct } \\
\text { operation for } \\
\text { solving } \\
\text { clinical case } \\
\text { problems. }\end{array}$ & $\begin{array}{l}\text { 1. Interaction } \\
\text { Based on } \\
\text { CIRS, teachers } \\
\text { display prob- } \\
\text { lems through } \\
\text { computers and } \\
\text { students an- } \\
\text { swer via smart } \\
\text { phones. } \\
\text { 2. Feedback. }\end{array}$ & 30 minutes \\
\hline
\end{tabular}




\begin{tabular}{|c|c|c|c|c|}
\hline & & & $\begin{array}{l}\text { Evaluation, } \\
\text { statistics and } \\
\text { analysis of } \\
\text { results by } \\
\text { CIRS or teach- } \\
\text { ers and think } \\
\text { about the } \\
\text { results }\end{array}$ & \\
\hline $\begin{array}{l}\text { Integrated mastery } \\
\text { and test applica- } \\
\text { tion }\end{array}$ & $\begin{array}{l}\text { Further facilitate } \\
\text { learners to apply } \\
\text { new knowledge } \\
\text { and skills to } \\
\text { clinical practice } \\
\text { and improve } \\
\text { students' ability } \\
\text { to solve practical } \\
\text { problems. }\end{array}$ & $\begin{array}{l}\text { 1. Guide } \\
\text { students to } \\
\text { think about } \\
\text { other similar } \\
\text { clinical } \\
\text { cases, and } \\
\text { then provide } \\
\text { examples. } \\
2 . \text { Propose } \\
\text { new ques- } \\
\text { tions. }\end{array}$ & $\begin{array}{l}\text { 1. Enlighten } \\
\text { and guide. } \\
\text { Enlighten } \\
\text { students to } \\
\text { think about } \\
\text { other cases. } \\
2 \text {. Present } \\
\text { contents. } \\
\text { Present the } \\
\text { specific con- } \\
\text { tent of the new } \\
\text { problems in } \\
\text { CIRS. } \\
\text { 3. Students re- } \\
\text { think and } \\
\text { expand auton- } \\
\text { omously. } \\
\text { Students } \\
\text { explore auton- } \\
\text { omously after } \\
\text { class and seek } \\
\text { solutions. }\end{array}$ & 15 minutes \\
\hline Summary and reflection & \multicolumn{4}{|c|}{$\begin{array}{l}\text { The internal medicine teaching course is based on 5-Star Instruction- } \\
\text { al Model basis and CIRS. Under the guidance of 5-Star Instructional } \\
\text { Model, this study goes from the easy to the difficult and simplifies } \\
\text { from abstract to explicit for teacher-student interaction through } \\
\text { smartphone CIRS and conducted evaluation. There are mainly three } \\
\text { steps. Firstly, the teacher creates an interactive activity and the } \\
\text { students respond, i.e. the teacher designs different questions accord- } \\
\text { ing to the teaching tasks and teaching contents, and the students } \\
\text { input answers and submit. Secondly, the teacher assesses the stu- } \\
\text { dent's grades and then gives real-time feedback. The system may } \\
\text { conduct statistics of some questions such as choice questions, com- } \\
\text { pletion questions fill in the blanks, true or false, etc. Teacher may } \\
\text { manual score subjective questions or ask students to questions after } \\
\text { releasing answers and criteria and opening cross-scoring function. } \\
\text { Thirdly, the CIRS statistically analyzes students' answers and out- } \\
\text { puts statistical data to reflect the students' learning situation for } \\
\text { teacher to adjust the teaching, and answer questions based on the } \\
\text { statistical results. The whole process is under the guidance of 5-Star } \\
\text { Instructional Model. }\end{array}$} \\
\hline Introduction of works & \multicolumn{4}{|c|}{$\begin{array}{l}\text { Under the principle of 5-Star Instructional Model focusing on prob- } \\
\text { lem-solving, the teaching process includes four continuously cycling } \\
\text { stages: activating original knowledge-- displaying and demonstrating } \\
\text { new knowledge-- trying application exercise--integrated mastery. } \\
\text { The outer layers of the four stages of continuous circulation are: } \\
\text { structure-guidance-coaching-self-examination, which shows that 5- } \\
\text { Star Instructional Model not only pays attention to the teaching } \\
\text { process, but also emphasizes the learning process. The teacher's } \\
\text { teaching process and students' learning process should be consistent. }\end{array}$} \\
\hline
\end{tabular}




\begin{tabular}{|l|l|}
\hline $\begin{array}{l}\text { CIRS as a relatively new type of classroom teaching media can help } \\
\text { teachers and students to establish an interactive learning model by } \\
\text { means of collecting, transmitting, processing and displaying infor- } \\
\text { mation. Each student has a mobile electronic device for signal } \\
\text { transmission to answer the teacher's questions and participate in the } \\
\text { teaching activities. Teachers use the feedback results displayed by } \\
\text { computers and other devices to control students' learning process } \\
\text { and to adjust teaching strategies and contents any time. }\end{array}$ \\
\hline
\end{tabular}

\subsection{Teaching effect}

This study selected two classes of S university internal medicine majors for teaching experiments, and divided into experimental class and control class, 45 students in each class. The experimental class received smartphone CIRS based on 5-Star Instructional Model for internal medicine teaching. The control class still adopted the traditional teaching method. To reduce the influence of other factors on the experimental results, the internal medicine teaching course scores of two classes within a previous year were similar, and the course teacher remained the same. From September to December 2017, this study conducted a one-semester teaching experiment, and investigated the attitude of students' in the experimental class towards smartphone CIRS based on after were compared with the teaching mode of the interactive teaching system of the smart phone teaching based on 5-Star Instructional Model, and compared the internal medicine teaching scores between the experimental class and the control class so as to analyze the influence of smartphone CIRS based on 5-Star Instructional Model on internal medicine teaching.

Students' attitude towards internal medicine teaching interactive course based on 5-Star Instructional Model: The results of investigation on the experimental class students' attitude to internal medicine teaching interactive course based on 5Star Instructional Model after the experiment are shown in Table 4. $91.1 \%$ of the students believed that the teaching model improved students' interest in internal medicine teaching, and $75.6 \%$ of the students believe that the teaching model improved the ability to connect theory with practice. $64.4 \%$ of students believed that the teaching model strengthened their ability to analyze and solve problems. $73.3 \%$ of the students believed that the teaching model improved their ability of information retrieval and information resource integration. $84.4 \%$ of the students believed that the teaching model strengthened learning convenience, and $91.1 \%$ of the students believe that the teaching model enriched the teaching form and means. $84.4 \%$ of the students believed that the teaching mode promoted teacher-student communication and $80.0 \%$ of the students believe that the teaching mode enhanced internal medicine teaching effect. The investigation results showed that students had a pro-attitude towards smartphone CIRS based on 5-Star Instructional Model for internal medicine teaching. 
Paper-Construction and Application of Internal Medicine teaching interactive course..

Table 4. Students' attitude towards internal medicine teaching interactive course based on 5Star Instructional Model

\begin{tabular}{|l|c|c|c|}
\hline \multicolumn{1}{|c|}{ Item } & Helpful & Fair & Not helpful \\
\hline To improve students' interest in internal medicine teaching & $41(91.1 \%)$ & $3(6.7 \%)$ & $1(2.2 \%)$ \\
\hline To improve the ability to connect theory with practice & $34(75.6 \%)$ & $6(13.3 \%)$ & $5(11.1 \%)$ \\
\hline To improve ability to analyze and solve problems & $29(64.4 \%)$ & $9(20.0 \%)$ & $7(15.6 \%)$ \\
\hline $\begin{array}{l}\text { To improve the ability of information retrieval and information } \\
\text { resource integration }\end{array}$ & $33(73.3 \%)$ & $8(17.7 \%)$ & $4(8.9 \%)$ \\
\hline To strengthen learning convenience & $38(84.4 \%)$ & $4(8.9 \%)$ & $3(6.7 \%)$ \\
\hline To enrich the teaching form and means & $41(91.1 \%)$ & $2(4.4 \%)$ & $2(4.4 \%)$ \\
\hline To promote teacher-student communication & $38(84.4 \%)$ & $4(8.9 \%)$ & $3(6.7 \%)$ \\
\hline To enhance internal medicine teaching effect & $36(80.0 \%)$ & $5(11.1 \%)$ & $4(8.9 \%)$ \\
\hline
\end{tabular}

Comparison of internal medicine course final scores between the experimental class and the control class: After the experiment, the final grades of the experimental and control classes were compared. The results are shown in Table 5 below. There were 8 people in the experimental class above 90 points, accounting for $17.8 \%$; 18 people in $80-89$ points, accounting for $40.0 \%$; 14 people in $70-79$ points, accounting for $31.1 \%$; 3 people in $60-69$ points, accounting for 3 Compared with $6.7 \%$; there are 2 people below 60 points, accounting for $4.4 \%$. There were 3 people in the control class with more than 90 points, accounting for $6.7 \%$; 8 people with $80-89$ points, accounting for $17.8 \%$; 17 people with $70-79$ points, accounting for $37.8 \%$; and those with 60-69 points, accounting for 9 More than 20.8\%; below 60 , there are 8 people, accounting for $17.8 \%$. The average grade of the experimental class was 82.6 points, the average score of the control class was 75.8 points, and the average grade of the experimental class was nearly 7 points higher than the control class. It shows that the interactive feedback course of smart phone teaching based on the five-star teaching theory has a positive effect on internal medicine teaching.

Table 5. Comparison of internal medicine course final scores between the experimental class and the control class

\begin{tabular}{|l|c|c|c|c|c|c|}
\hline \multirow{2}{*}{ Group } & \multirow{2}{*}{$\begin{array}{c}\text { Average } \\
\text { scores }\end{array}$} & \multicolumn{5}{|c|}{ Number of people in each score section } \\
\cline { 5 - 7 } & & Under 60 & $\mathbf{6 0 - 6 9}$ & $\mathbf{7 0 - 7 9}$ & $\mathbf{8 0 - 8 9}$ & Above 90 \\
\hline $\begin{array}{l}\text { Experimental class } \\
(\mathrm{n}=45)\end{array}$ & 82.6 & $2(4.4 \%)$ & $3(6.7 \%)$ & $14(31.1 \%)$ & $18(40.0 \%)$ & $8(17.8 \%)$ \\
\hline Control class (n=45) & 75.8 & $8(17.8 \%)$ & $9(20.0 \%)$ & $17(37.8 \%)$ & $8(17.8 \%)$ & $3(6.7 \%)$ \\
\hline
\end{tabular}




\section{Conclusion}

5-Star Instructional Model has become a brand-new teaching theory which can facilitate effective teaching in the new era. CIRS has gradually become a multimedia teaching means. Teaching with students' own smart phones expects to become a popular trend. Based on 5-Star Instructional Model, this study built a smartphone CIRS through powerful combination. It can provide a new teaching concept for improving teaching quality maximally. The experiment results also show the internal medicine interactive course based on 5-Star Instructional Model can significantly improve the students' academic scores of internal medicine learning, strengthen students' learning interest at the same time, enhance students' problem-solving ability and obtain good teaching results. The teaching mode has significant advantages. 5-Star Instructional Model provides theoretical guidance for the teaching process, helps teachers to develop clear teaching thoughts and logic, and guarantees teaching activities to be carried out smoothly. The low-cost, simple and effective smartphone CIRS itself cannot promote teaching, but it provides teaching means and methods for the teaching process, which can significantly improve the probability of students' classroom participation and provide timely feedback of students' learning status, adjust the teaching contents, and help students' in-depth understanding and cognition of knowledge. Combining both can help to obtain the optimum efficiency in teaching and training of medical professional talents. However, it requires to pay attention to some problems when using this mode for teaching. 5-Star Instructional Model combined with smartphone CIRS with high requirements for teaching design should closely integrate teaching objectives, and focus on students' development level and psychological status. During the teaching process, it is necessary to adjust temporarily, adapt to changes, and control the teaching progress so as to guarantee no deviation from teaching tasks, which obviously sets high requirements for teachers' teaching attainment, and brings certain pressure for teachers. Teachers may not implement the teaching mode from beginning to end due to ability deficiency. Thus, it is necessary to strengthen training for teachers, and intensify teachers' understanding and application of 5-Star Instructional Model and smartphone CIRS. Smartphone CIRS with extremely high requirements for the network environment can greatly influence teaching and even interrupt the teaching in case of power failure, electronic equipment damage or network interruption, causing teaching failure. Thus, it is necessary to pay special attention to the network environment management and maintenance. At the same time, it is necessary to pay attention to the issue of students" "obsession to mobile phone", avoid students to use smart phones for other activities irrelevant to teaching in the name of participating in interactive learning. Therefore, it requires to further improve the combination of 5-Star Instructional Model and smartphone CIRS for internal medicine teaching in future studies. 


\section{Acknowledgement}

This work was supported by Key projects of Natural Science in Anhui (KJ2017A716) and Key projects of Natural Science in Anhui (KJ2017A717).

\section{$7 \quad$ References}

[1] Salter, D., Richards, R., Carey, T. The 'T5' Design Model: An Instructional Model and Learning Environment to Support the Integration of Online and Campus - Based Courses. Educational Media International, 2004, vol. 41(3), pp. 207-218. https://doi.org/10.1080/ 09523980410001680824

[2] Starr, S. Improving instruction in medical libraries: The research agenda. Journal of the Medical Library Association Jmla, 2012, vol. 100(4), pp. 236-238. https://doi.org/10.3163/ $\underline{1536-5050.100 .4 .003}$

[3] Ruge, H., Wolfensteller, U. Functional integration processes underlying the instructionbased learning of novel goal-directed behaviors. Neuroimage, 2013, vol. 68(3), pp. 162172. https://doi.org/10.1016/j.neuroimage.2012.12.003

[4] Datta, R., Datta, K., Venkatesh, M.D. Evaluation of interactive teaching for undergraduate medical students using a classroom interactive response system in India. Medical Journal Armed Forces India, 2015, vol. 71(3), pp. 239-245. https://doi.org/10.1016/j.mjafi.2015. $\underline{04.007}$

[5] Robin, K., Ann, L., Liesel, K. Examining the Use of Audience Response Systems in Secondary School Classrooms: A Formative Analysis. Journal of Interactive Learning Research, 2010, vol. 21(21), pp. 343-365.

[6] Lu, Q., Luo, W., Du, L. Practice of classroom response teaching method in the sensor and testing technology course based on interactive response system. China Modern Educational Equipment, 2014, vol. 17, pp. 62-64.

[7] Li, L.B. Facing the Future, Promoting Sharing, Promoting Integration and Leading Innovation-Review on the ten year development plan of education informatization (2011-2020 years). Information Technology Education, 2012, vol. 5, pp. 4-5.

[8] Collis, B., Margaryan, A. Design criteria for work-based learning: Merrill's First Principles of Instruction expanded. British Journal of Educational Technology, 2005, vol. 36(5), pp. 725-738. https://doi.org/10.1111/j.1467-8535.2005.00507.x

[9] Dow, M.J. Meeting Needs: Effective Use of First Principles of Instruction. School Library Monthly, 2013, vol. 29, pp. 8-10.

[10] Cheung, W.S., Hew, K.F. Applying "First Principles of Instruction" In a Blended Learning Course. Communications in Computer \& Information Science, 2015, vol. 494(1), pp. 3944. https://doi.org/10.1007/978-3-662-46158-7_13

[11] Zhang, W. Application of five star teaching principle in modern Chinese micro teaching. Survey of Education, 2016, vol. 5(10), 77-79.

[12] Ren, J.L. 论Application of five-star teaching mode in the social research method course in Colleges and Universities. Journal of the College of Northwest Adult Education, 2018, vol. 1, pp. 64-69.

[13] Blackwell, C., McKee, M. Alchian and Allen visit the IRS: costly audits and taxpayer compliance. Applied Economics Letters, 2012, vol. 19(17), pp. 1731-1734. https:// doi.org/10.1080/13504851.2012.667541 
Paper-Construction and Application of Internal Medicine teaching interactive course...

[14] Aldabbagh, S.A., Al-Taee, W.G. Evaluation of a task-based community oriented teaching model in family medicine for undergraduate medical students in Iraq. Bmc Medical Education, 2005, vol. 5(1), pp. 1-12.

\section{Author}

Qiong Fang is an associate professor in the Hefei Technology College, Hefei, China(18355365221@163.com).

Article submitted 6 October 2018. Resubmitted 8 December 2018. Final acceptance 16 December 2018. Final version published as submitted by the author. 